\begin{tabular}{|c|c|}
\hline \multicolumn{2}{|c|}{ Access this article online } \\
\hline Quick Response Code: & \multirow{2}{*}{$\begin{array}{l}\text { Website: } \\
\text { www.annalsafrmed.org }\end{array}$} \\
\hline \multirow{3}{*}{ 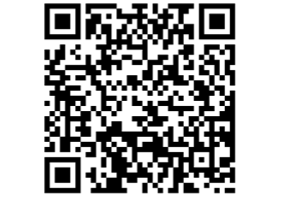 } & \\
\hline & $\begin{array}{l}\text { DOI: } \\
10.4103 / 1596-3519.129857\end{array}$ \\
\hline & $\begin{array}{l}\text { PMID: } \\
* \star \star \star \star \star\end{array}$ \\
\hline
\end{tabular}

\title{
Cervical spondylosis in South West Nigerian farmers and female traders
}

\author{
S. A. Oguntona \\ Department of Medicine, Rheumatology Unit, Olabisi Onabanjo University, Sagamu, Ogun State, Nigeria
}

Correspondence to: Dr. Oguntona SA, Post Box 231, Sagamu, Ogun State, Nigeria. E-mail: oguntonasa@yahoo.com

\begin{abstract}
Background: Neck pain is a common pain syndrome in the clinical practice. It may or may not be associated with the radiculopathy or myelopathy. Load carrying on the head is believed to be associated with an increased incidence of cervical spondylosis. Radiographic spondylosis is noticeable in $25-50 \%$ of people of 50 years of age and in $75-90 \%$ by the age of 65 years.

Materials and Methods: Plain cervical radiograph were obtained in all farmers and female traders above 45 years of age who complained of neck pain. Those who met the radiological diagnostic criteria were enlisted in the study. The study was carried out over a 3 year period (July 2009-June 2012) in a private rheumatology clinic.

Results: Thirty six cases of cervical spondylosis were seen, representing $10.7 \%$ of a total rheumatology cases seen over the study period. There were 23 males (63.9\%) and 13 females (36.1\%), giving a male: Female ratio of 1.8:1. There were 18 male farmers, 5 female farmers, and 5 female traders. Eight males and 6 females showed severe degenerative changes in the cervical spine. Mostly affected were $\mathrm{C} 4-\mathrm{C} 7$ cervical spine levels.

Conclusion: Load carrying, as earlier documented in literature may be a significant contributory factor to the degenerative process of the cervical spine.
\end{abstract}

Keywords: Cervical spondylosis, farmers and traders, Nigeria, south west

\section{Résumé}

Fond: Douleur au cou est un syndrome de douleur commune dans la pratique clinique. Il peut ou peut ne pas être associé à la radiculopathie ou myélopathie. Charge sur la tête est censée être associée à une incidence accrue d'arthrose cervicale. Spondylose radiographique est perceptible chez 25 à $50 \%$ des personnes de 50 ans d'âge et dans 75 à $90 \%$ par l'âge de 65 ans.

Matériaux et méthodes: Plaine radiographie cervicale ont été obtenus dans tous les agriculteurs et les commerçants femelles plus de 45 ans qui se plaignaient de douleurs au cou. Ceux qui répondaient aux critères diagnostiques radiologiques ont été enrôlés dans l'étude. L'étude a été réalisée sur une période de 3 ans (juillet 2009-juin 2012) dans une clinique privée de rhumatologie.

Résultats: Trente-six cas d'arthrose cervicale ont été vus, soit 10,7 \% d'un rhumatologie total cas observés au cours de la période d'étude. Il y a 23 hommes $(63,9 \%)$ et 13 femelles $(36,1 \%)$, ce qui donne un mâle: fEmme ratio de 1. Il y avait 18 agriculteurs mâles, 5 agricultrices et 5 commerçants femelles. Huit mâles et 6 femelles montrent des modifications dégénératives graves dans le rachis cervical. Touchés pour la plupart étaient des niveaux du rachis cervical C4-C7.

Conclusion: Charge, comme nous l'avons documenté dans la littérature peut être un facteur important pour le processus de dégénérescence du rachis cervical.

Mots-clés : Arthrose cervicale, agriculteurs et commerçants, Nigeria, sud ouest 


\section{Introduction}

Cervical spondylosis is a degenerative disease of the cervical spine, intervertebral discs, ligaments and cartilaginous materials, and it is commonly seen in people above age 40 years. It is believed to be part of the normal aging process of the vertebral column. ${ }^{[1,2]}$ Radiological investigation of asymptomatic individuals showed spondylotic changes of greater than $50 \%$ by age 50 years and up to $90 \%$ by age of 65 years. ${ }^{[3]}$

Risk factors for cervical spondylosis include age, and occupation. ${ }^{[4,5]}$ Others include previous neck injuries, familial, and genetic factors. Certain jobs may place extra stress on the neck.

Cervical spondylosis usually produces intermittent neck pain in middle aged and elderly patients. ${ }^{[6,7]}$ There are several main clinical syndromes, which are described in relation to cervical spondylosis. Cervical spondylotic myelopathy, cervical radiculopathy, and neck pain syndrome. ${ }^{[8]}$

Plain radiographs are rarely diagnostic, and pain severity correlates poorly with the radiographic abnormalities. ${ }^{[9]}$ Magnetic resonance imaging (MRI) can detect disc and cord abnormalities computerized tomography will evaluate bone abnormalities, and electromyography, and nerve conduction studies can localize and assess the severity of the nerve root injury. ${ }^{[10]}$

Medical management includes pharmacological and rehabilitation components. ${ }^{[11]}$ Non-operative management involves the use of medications such as non-steroidal anti-inflammatory drugs, muscle relaxants, analgesics, antidepressants, and anticonvulsants. ${ }^{[12]}$

\section{Materials and Methods}

\section{Study population}

The study was conducted in a private rheumatology clinic in the south-west of Nigeria. The studied populations were farmers and female traders who carry heavy loads on their heads and reside in the south-west region of Nigeria. They presented with history of neck pain at the rheumatology consultation clinic after a variable period of heavy load carrying on their heads. Neck pain was defined as pain or discomfort experienced in the neck for at least a few hours during the past 12 months.

Lateral radiograph of all patients were obtained and were reported by a consultant radiologist who was blinded about the occupation of the study subjects.
Finding of the following radiological features in the lateral radiograph of the cervical spine was considered as having spondylosis:

- Sclerosis of the interfacet joint

- Presence of osteophytes

- Narrowing of the disc spaces

- Loss of normal alignment of the cervical spine.

Patients with definite evidence of cervical spinal injury were excluded from the study.

MRI was not requested for because of affordability.

\section{Results}

Table 1 shows the commonly found musculoskeletal conditions among the people of South West, Nigeria. Thirty six cases of cervical spondylosis were seen over the study period representing $10.7 \%$ of total cases of rheumatology cases seen. Twenty three were males representing $63.9 \%$ and 13 females $36.1 \%$ with a male:Female ratio of $1.8: 1$. Mean age at presentation was 52 years. Twenty eight (77.8\%) of these patients were involved in carrying a heavy load on their heads and $14(50 \%)$ of this group showed severe radiological spondylotic changes. Mostly affected cervical spines were C4/C5, C5/C6, and C6/C7 levels. One patient presented with radiculopathy while another one presented with the myelopathic quadriparesis.

\section{Discussion}

Carrying heavy objects on the head is a very common practice in some African countries. ${ }^{[13]}$ Apart from the age being a predisposing factor to the cervical spondylosis, load carrying on the head has also been found to exacerbate a degenerative process in the spine. Jäger $e t$ al. evaluated in a case control study the relationship between the load carrying on the head and the development of degenerative changes in the cervical spine of 70 Ghanaians. ${ }^{[14]}$ In 31 of the $35(89 \%)$ carriers, degenerative changes were found in the cervical spine, but only in 8 of the 35 (23\%) non-carriers. ${ }^{[15]}$

Carrying loads on the head imposes a considerable amount of strain on the axial skeleton. ${ }^{[14,16]}$ The practice of carrying heavy loads, weighing $50 \mathrm{~kg}$ and above on their head is very common among farmers and traders in the south west Nigeria. Accordingly, they are at increased risk of developing cervical spondylosis.

Degenerative change in the cervical spine correlates very closely with the aging process. ${ }^{[17]}$ The mean age of affected people in this study was 52 years, which corresponded with earlier studies. Pallis et al. found that 


\begin{tabular}{lccccc}
\hline Table 1: Commonly found musculoskeletal conditions among the people of South West, Nigeria (July 2009-June 2012) \\
\hline Condition & Number & Male & Percentage & Female & Percentage \\
\hline Osteoarthritis of the knee & 104 & 32 & 30.8 & 72 & 69.2 \\
Rheumatoid arthritis & 12 & 4 & 33.3 & 8 & 66.7 \\
Cervical spondylosis & 36 & 23 & 63.9 & 13 & 36.1 \\
Lunbar spondylosis & 25 & 21 & 56 & 14 & 44 \\
Non-specific low back pain & 48 & 37 & 77.1 & 11 & 22.9 \\
Gout & 28 & 22 & 78.6 & 6 & 21.4 \\
SLE & 6 & 1 & 16.7 & 5 & 83.3 \\
Shoulder pain syndrome & 12 & 4 & 33.3 & 8 & 66.7 \\
Hypermobility syndrome & 8 & 0 & 0 & 8 & 100 \\
Fibromyagia & 6 & 0 & 0 & 6 & 100 \\
Polymyalgia rheumatica & 2 & 0 & 0 & 2 & 100 \\
Bursitis & 4 & 3 & 75 & 1 & 25 \\
Trigger finger & 16 & 6 & 37.5 & 10 & 62.5 \\
Sjorgren's syndrome & 1 & 0 & 0 & 1 & 100 \\
Reiter's syndrome & 1 & 1 & 100 & 0 & 0 \\
Septic arthritis & 2 & 0 & 0 & 2 & 100 \\
Lateral epicondylitis & 2 & 2 & 100 & 0 & 0 \\
Medial epicondylitis & 2 & 2 & 100 & 0 & 0 \\
Scleroderma & 2 & 0 & 0 & 2 & 100 \\
Psoriatic arthropathy & 1 & 1 & 100 & 0 & 0 \\
Plantar fasciitis & 7 & 2 & 28.6 & 5 & 71.4 \\
Carpal tunnel syndrome & 3 & 1 & 33.3 & 2 & 66.7 \\
Archilis tendinitis & 8 & 1 & 12.5 & 7 & 87.5 \\
& 336 & 160 & & 176 & \\
\hline
\end{tabular}

cervical spondylosis was a disease of the elderly affecting mostly those over 50 years. ${ }^{[18]}$ In a study among patients with the cervical spondylosis in Bangladesh, Ahmed et al. found that the maximum number of cases $(60 \%)$ was in the age group above 50 years. ${ }^{[19]}$

Half of those who carry a heavy load on their head in this study showed severe radiological changes. However, no study has been able to establish the severity of cervical spondylosis with weight of load carried. Correlation of radiographic changes in cervical spondylosis with the clinical symptoms is also poor. ${ }^{[20,21]}$ Many individuals with radiographic evidence of cervical spondylosis may be totally asymptomatic, and many with the symptomatic spondylosis showed little or no radiographic changes. ${ }^{[22]}$ Differences in the pre-morbid size of the cervical spinal canal are considered to be the reason for this discrepancy. ${ }^{[23,24]}$

One patient $(2.8 \%)$ however presented with cervical radiculopathy. The natural history of cervical radiculopathy is that most patients have a favorable prognosis. ${ }^{[25]}$ A large epidemiologic study demonstrated that over a 5-year follow-up period, $90 \%$ of patients were asymptomatic or only mildly incapacitated by the pain. ${ }^{[26]}$ In another study with 51 cervical radiculopathy patients, who were followed-up for 2-19 years, $43 \%$ of patients had no further symptoms after a few months, $29 \%$ of patients had mild or intermittent symptoms, and $27 \%$ had more disabling pain. No patient with radicular pain; however, progressed to myelopathy. ${ }^{[27]}$
One other patient developed myelopathy. Above age 50 years, cervical spondylosis is the most common cause of spinal cord disorders. Diagnosis is usually delayed in this age group because presentation may be subtle and that there is no pathognomonic findings. ${ }^{[26]}$ In most cases, the disability is mild, and the prognosis good. ${ }^{[28]}$ Significant impairment of function may however, result, therefore, early recognition is crucial. The natural history of cervical myelopathy is best summarized as a gradual, progressive worsening of symptoms and decline in the functional status. The most common pattern is a progression of symptoms followed by periods of stable or worsening function and in rare instances, improvement. ${ }^{[29,30]}$ In a review of 120 patients, Clarke and Robinson identified a slow pattern of neurological function in $50 \%$ of patients, and a rapid pattern with stable interval in $25 \%$ of patients. ${ }^{[30]}$ Lees and Turner similarly defined stepwise neurological dysfunction with quiescent intervals. ${ }^{[29]}$

In many cases, non-surgical treatment does not treat conditions that cause the degenerative disorder of the spine. However, they might temporarily relieve pain. The natural history suggests that for the most part, patients with axial symptoms are best treated without surgery while some patients are unlikely to show significant improvement, and in the most cases will show stepwise deterioration. Surgical decompression and stabilization should be considered in these patients.

About $75 \%$ of patients have a significant relieve of symptoms with non-operative treatment. 
Studies of patients with non-operatively management suggest that $45-60 \%$ of patients have good resolution of symptoms with remainder continuing with moderate to severe residual pain. ${ }^{[31,32]}$ Operative management is indicated for the progressive neurological deterioration, intractable pain and documented compression of nerve roots or of the spinal cord that leads to progressive symptoms. ${ }^{[33]}$

Page 164

In conclusion, this study has shown that carrying heavy loads on the head has a positive significant relationship with cervical spondylosis and that heavy load carriers are more pre-disposed to developing severe cervical spondylosis.

\section{References}

1. Croft PR, Lewis M, Papageorgiou AC, Thomas E, Jayson MI, Macfarlane G], et al. Risk factors for neck pain: A longitudinal study in the general population. Pain 2001;93:317-325.

2. Côté P, Cassidy JD, Carroll L. The factors associated with neck pain and its related disability in the Saskatchewan population. Spine (Phila Pa 1976) 2000;25:1109-1117.

3. McCormack BM, Weinstein PR. Cervical spondylosis. An update. West ] Med 1996;165:43-51.

4. Hadjipavlou AG, Tzermiadianos MN, Bogduk N, Zindrick MR. The pathophysiology of disc degeneration: A critical review. ] Bone Joint Surg Br 2008;90:1261-1270.

5. Zejda JE, Stasiów B. Cervical spine degenerative changes (narrowed intervertebral disc spaces and osteophytes) in coal miners. Int J Occup Med Environ Health 2003;16:49-53.

6. Hartvigsen J, Christensen K, Frederiksen H. Back and neck pain exhibit many common features in old age: A population-based study of 4,486 Danish twins 70-102 years of age. Spine (Phila Pa 1976) 2004;29:576-580.

7. Goode AP, Freburger ], Carey T. Prevalence, practice patterns, and evidence for chronic neck pain. Arthritis Care Res (Hoboken) 2010;62:1594-1601.

8. Heller JG. The syndromes of degenerative cervical disease. Orthop Clin North Am 1992;23:381-394.

9. Johnson M], Lucas GL. Value of cervical spine radiographs as a screening tool. Clin Orthop Relat Res 1997;340:102-108.

10. Nakano KK. Neck pain. In: Ruddy S, Harris ED, Sledge CB, editors. Kelly's Textbook of Rheumatology. $6^{\text {th }}$ ed. Philadelphia: WB Saunders; 2001. p. 457-74.

11. Mazanec D, Reddy A. Medical management of cervical spondylosis. Neurosurgery 2007;60:S43-50.

12. Hardin JG, Halla JT. Cervical Spine Syndromes. In: Koopman W], editor. Arthritis and allied conditions. A Textbook of Rheumatology. $14^{\text {th }}$ edition. Philadelphia: Lippincott Williams and Wilkins; 2001. p. 2009-18.

13. Jumah KB, Nyame PK. Relationship between load carrying on the head and cervical spondylosis in Ghanaians. West Afr ] Med 1994;13:181-182.

14. Joosab M, Torode M, Rao PV. Preliminary findings on the effect of load-carrying to the structural integrity of the cervical spine. Surg Radiol Anat 1994;16:393-398.
15. Jäger H], Gordon-Harris L, Mehring UM, Goetz GF, Mathias KD. Degenerative change in the cervical spine and load-carrying on the head. Skeletal Radiol 1997;26:475-481.

16. Czech C, Czech R, Seibt A, Freude AD. Functional changes of the cervical spine and shoulder-neck region in workers employed in textile sewing. Z Gesamte Hyg 1990;36:61-64.

17. Mouw MD, Hitchon PW. Pathogenesis and natural history of degenerative disc and spinal disease. In: Tindall GT, Cooper PR, Barrow DL, editors. The Practice of Neurosurgery. Vol. 3. Baltimore: Williams \& Wilkins; 1996. p. 2357-65.

18. Pallis C, Jones AM, Spillane JD. Cervical spondylosis; incidence and implications. Brain 1954;77:274-289.

19. Ahmed Z, Khan M, Islam N. Cervical spondylosis. Asian Med ] 1992;25:271-7.

20. Connell MD, Wiesel SW. Natural history and pathogenesis of cervical disk disease. Orthop Clin North Am 1992;23:369-380.

21. Lawrence JS. Disc degeneration. Its frequency and relationship to symptoms. Ann Rheum Dis 1969;28:121-138.

22. Fenlin JM Jr. Pathology of degenerative disease of the cervical spine. Orthop Clin North Am 1971;2:371-387.

23. Lestini WF, Wiesel SW. The pathogenesis of cervical spondylosis. Clin Orthop Relat Res 1989;12:69-93.

24. Bohlmann HH, Emery SE. Pathophysiology of cervical spondylosis and myelopathy. Spine 1989;13:843-6.

25. Radhakrishnan K, Litchy W], O'Fallon WM, Kurland LT. Epidemiology of cervical radiculopathy. A populationbased study from Rochester, Minnesota, 1976 through 1990. Brain 1994;117:325-335.

26. Dvorak ], Sutter M, Herdmann J. Cervical myelopathy: Clinical and neurophysiological evaluation. Eur Spine ] 2003;12:S18 1-7.

27. Ono K, Ota H, Tada K, Yamamoto T. Cervical myelopathy secondary to multiple spondylotic protrusions. A clinicopathologic study. Spine 1977;2:109-125.

28. Ebara S, Yonenobu K, Fujiwara K, Yamashita K, Ono K. Myelopathy hand characterized by muscle wasting. A different type of myelopathy hand in patients with cervical spondylosis. Spine (Phila Pa 1976) 1988;13:785-791.

29. Lees F, Turner JW. Natural history and prognosis of cervical spondylosis. Br Med ] 1963;2:1607-1610.

30. Clarke E, Robinson PK. Cervical myelopathy: A complication of cervical spondylosis. Brain 1956;79: 483-510.

31. Binder A. Cervical Pain Syndrome. In: Maddison P], Isenberg DA, Woo P, editors. Oxford Textbook of Rheumatology. Oxford: Oxford University Press;1993. p. 1060-70.

32. Haldeman S, Carroll L, Cassidy JD, Schubert ], Nygren A, The Bone and Joint Decade 2000-2010. Task Force on Neck Pain and its Associated Disorders: Executive summary. Spine (Phila Pa 1976) 2008;33:S5-7.

33. Bernhardt M, Hynes RA, Blume HW, White AA $3^{\text {rd }}$. Cervical spondylotic myelopathy. ] Bone joint Surg Am 1993;75:119-128.

Cite this article as: Oguntona SA. Cervical spondylosis in South West Nigerian farmers and female traders. Ann Afr Med 2014; 13:61-4.

Source of Support: Nil, Conflict of Interest: None declared. 